\title{
Strengthening humanistic based character education through local values and Islamic education values in basic education units in purwakarta regency
}

\author{
*Muhamad Taufik Bintang Kejora, Universitas Singaperbangsa Karawang \\ muhamad.taufik@fai.unsika.ac.id,ORCID:0000-0003-3966-0981 \\ Achmad Junaedi Sittika, Universitas Singaperbangsa Karawang, achmad.junaedi@staff.unsika.ac.id, \\ ORCID: 0000-0003-3774-5834
}

Ahmad Syahid, Universitas Singaperbangsa Karawang, ahmad.syahid@fkip.unsika.ac.id, ORCID: 00000002-9223-6920

\begin{abstract}
The character crisis becomes an educational problem that demands solutions that prioritize humanistic efforts in developing character from an early age in elementary schools. Realizing the importance of character building. The Purwakarta district government made changes to the education system by prioritizing Islamic education values and Sundanese local wisdom through the Tujuh Poe Atikan Purwakarta Istimewa program as outlined in Purwakarta since 2015. The results showed that elementary schools in Purwakarta district implemented character education based on different themes every day. Education focuses on the skills and potential of children through active learning, fun and not burdening students. From the aspect of the curriculum, the lessons that are included in the curriculum are adjusted to the local schools and aim to form a generation of cageur, bageur, bener, singer, and pinter. Children learn by prioritizing four pillars of education through the good exemplary, habituation, motivating, cultivating, and enforcing rules.
\end{abstract}

Keywords: Character Education, Humanistic, Local Wisdom, Islamic Education

Received: 08.12.2020 $\quad$ Accepted: 21.01.2021 $\quad$ Published: 02.02.2021

\section{INTRODUCTION}

The world of education in Indonesia has experienced very sharp criticism as a reaction to rampant violence, social violations, immoral violations, narcotics abuse, promiscuity, fading of the spirit of nationalism, erosion of religious tolerance, loss of respect and low level of mutual cooperation among students as the nation's next generation (Rahim, Raisul, \& Abdoludin, 2016: 159). In fact, not a few also give a negative stigma that education has failed, because many school graduates are skilled in answering exam questions but are powerless to answer life's problems at hand (Latiep, 2014: 440).

The fading of character values is alleged to be one of the causes of the moral downturn that occurs in society (Durachman, 2014: 341). Our character education practices have been too Western-oriented, forgetting the values of Islamic education and the superior characteristics of local wisdom that have been growing in society (Sugiyo \& Purwastuti, 2017: 301). Whereas in fact the basis for character development is the theological foundation by which humans will be able to develop ideas in achieving religious perfection so that they become human beings who are human beings (noble characters) (Maisaro, Wiyono, \& Arifin, 2018). On the other hand, as social beings, humans interact with each other and develop their values, norms and culture. This has been taught from generation to generation to become a local wisdom that guides people to gain goodness and improve life in accordance with the characteristics of society and the environment (Fajrussalam \& Hasanah, 2018: 15).

One alternative to overcome the problem of character crisis that hit this nation is through strengthening character education that prioritizes a humanistic approach in the educational process (Fitri, 2020: 37). The humanistic paradigm holds that education is an effort to humanize humans. Good and true education is a strategic and effective effort to help optimize and actualize human potential (Baharrudin \& Makin, 2011: 113). No matter how modern education is today, it will not produce real success and benefits if human questions cannot be answered and are not conclusively defined. Thus, a humanistic approach in character education is needed so that children are able to know themselves, know their creators, know their environment, know their culture, know their nature, and know their purpose in life (Usman, Shaharudin \& Abidin, 2017: 98). 
Psychological studies of students explain that the age of children who are most effective in instilling character is the age of seven to twelve years. This age is the range of primary school age where every experience and events experienced by the child can affect the child's development at the next stage of development. It can also be said that this age is the golden age as the foundation for a child's future. So, it is appropriate if character education is implemented from an early age, especially at the elementary school level (Paryana, 2014: 322).

Realizing the importance of strengthening character education from an early age in facing challenges in the era of globalization and the industrial revolution, the Purwakarta district government made changes to the primary school education system by raising awareness of the religious and cultural dimensions by bringing up local wisdom of the Sundanese people (Cece, 2019: 77). This is stated in the Regent Regulation Number 69 of 2015 concerning Character Education. The Purwakarta district government builds character through the 7 Poe Atikan Istimewa Purwakarta Istimewa program (Permatasari \& Hakam, 2018: 145).

The "Tujuh Poe Atikan Istimewa Purwakarta Istimewa" is a character education by prioritizing Sundanese culture and contains seven programs that must be implemented every day. This program refers to the values of Islamic teachings as the majority religion adhered to by the community and local culture, namely Sundanese culture (Permatasari \& Hakam, 2018: 150). The values of Islamic education that are implemented in schools include the character values contained in the Al-Qur'an Surat Lukman verses 12-19, namely gratitude, tawhid, ihsan, patience, devotion to parents, not arrogant and arrogant, simple, and please- help (Anshari \& Widyantoro, 2020: 22). This program also aims to form a humanistic young generation in accordance with the values of the Sundanese people in West Java, namely: cageur, bageur, bener, pinter jeung singer (Aziz, 2018: 15). With this policy, the sustainability of education in Purwakarta district is based on the program "Tujuh Poe Atikan Purwakarta Istimewa" must be integrated in various activities in schools with the breath of local wisdom and Islamic educational values (Taufan \&Sapriya, 2018: 18)

The educational reform in Purwakarta district has the view that education should not be handcuffed to students. Education must be able to facilitate transformative and democratic students to achieve self-actualization of knowing themselves, knowing their God, knowing their environment, knowing their culture and knowing their nature. Education must be able to explore and develop the potential of students who are useful for themselves to answer the challenges of life in the future. Education must involve an educational trip center in realizing the vision and mission of Purwakarta Character. This view strengthens the position of character education, which is an effort to humanize humans to become human beings with noble character as the goal of education in the National Education System Law Number 20 of 2003 (Cece, 2019: 177). Education must be able to treat and shape humans as humans as they should (Hartono, Haryanto, \& Asrowi, 2018: 101). For this reason, efforts to strengthen character education in a humanistic manner are a solution and a challenge in building children's character from an early age (Taufik, 2020: 92). From the description above, it is very clear that to succeed in strengthening character education in elementary schools, it is necessary to prioritize humanistic efforts by raising the values of local wisdom and the values of Islamic education in schools. This needs to be a strategic effort and an inevitable necessity so that students acquire complete knowledge, skills and attitudes that make them lifelong learners.

\section{METHODS}

\section{Research method}

This research is an educational research that focuses on the concept and model of implementation of humanistic-based character education policies through local wisdom and values of Islamic education in basic education units. This research is a qualitative descriptive study (Kusdarini, Sunarso, \& Arpannudin, 2020: 361). This research is based on observations over the last four years, namely (from 2016-2020) where the Purwakarta district government conducted policy studies, especially at the basic education level to create a special Purwakarta with character. The Purwakarta district government established 17 culture-based elementary schools in each sub-district. Thus, the research involved 17 public elementary schools which were pilot schools for character education in the Purwakarta district.

Data collection technique and analysis

Data collection was carried out through interviews, documentation, and observation using preprepared data collection tools including interview guidelines, documentation checklist sheets, and observation sheets (Moleong, 2018: 66). Interviews were conducted with policy makers, supervisors, school principals, teachers, parents of students, school committees, and community leaders. Documentation includes documentation of activities and collection of other related documents. 
Observations were made to objectively see activities in strengthening character education. Data were collected and analyzed using qualitative descriptive techniques and triangulation to obtain accurate and accountable data by matching the data obtained through interviews, documentation and observations monitored and guided by the research team (Moleong, 2018: 67).

\section{RESULTS}

\section{Strengthening Character Education In Indonesia}

Strengthening Character Education is a continuation and revitalization of the national character education movement that began in 2010. Strengthening Character Education values are the main values that need to be developed and become a priority in the mental revolution (Suherman, Supriyadi, \& Cukarso, 2019: 126). Through the Presidential Regulation of the Republic of Indonesia Number 87 of 2017 concerning Strengthening Character Education, character education which previously included 18character values was strengthened into 5-character values namely religious, nationalist, integrity, independence and mutual cooperation (Subaidi, 2020: 125).

These character values are the basic values that are implemented and integrated in every educational and teaching activity at every level of basic education nationally, especially in Purwakarta district. Through strengthening character education, it is hoped that it will be able to build and equip students to become the golden generation of Indonesia in 2045 with the spirit of Pancasila and good character education to face the dynamics of change in the future (Taufik, 2020: 95).

Tabel 1. Values of Strengthening Character Education in Elementary School Students

\begin{tabular}{|l|l|l|l|}
\hline No & $\begin{array}{l}\text { Value } \\
\text { Dimension }\end{array}$ & Explanation & Sub Value \\
\hline 1. & Religious & Reflects the faith in God Almighty. & $\begin{array}{l}\text { Love peace, tolerance, respect, } \\
\text { differences in religion and } \\
\text { belief, anti bullying and } \\
\text { violence. }\end{array}$ \\
\hline 2. & Nasionalist & $\begin{array}{l}\text { A way of thinking and behaving that } \\
\text { shows concern and respect for the } \\
\text { nation's language, environment, social, } \\
\text { culture, economy and politics }\end{array}$ & $\begin{array}{l}\text { Willing to sacrifice, excellence, } \\
\text { and achievers, love the } \\
\text { country, protect the } \\
\text { environment, obey the law, } \\
\text { discipline, respect cultural, } \\
\text { ethnic and religious diversity. }\end{array}$ \\
\hline 3. & Independent & $\begin{array}{l}\text { Attitudes and behavior are independent } \\
\text { of others. }\end{array}$ & $\begin{array}{l}\text { Work ethic (hard work), } \\
\text { professional, and creative. }\end{array}$ \\
\hline 4. & Integrity & $\begin{array}{l}\text { The values that underlie behavior in } \\
\text { order to create a trusted person. }\end{array}$ & $\begin{array}{l}\text { Honesty, anti-corruption, } \\
\text { fairness and responsibility. }\end{array}$ \\
\hline 5. & Cooperation & $\begin{array}{l}\text { Reflects the act of appreciating the spirit } \\
\text { of cooperation in solving common } \\
\text { problems and providing assistance } \\
\text { especially to people in need. }\end{array}$ & $\begin{array}{l}\text { Respect, } \\
\text { commitment to joint decisions, } \\
\text { deliberation to reach a } \\
\text { consensus, please help, and } \\
\text { solidarity. }\end{array}$ \\
\hline
\end{tabular}

Character education policy in Purwakarta regency

Since 2014 the Purwakarta district government has made changes to the primary school education system by raising awareness of the dimensions of religion and culture by raising local wisdom of the Sundanese people (Hude, Febrianti, \& Cece, 2019: 390). In other words, the spirit of "Mental Revolution" was already running even before President Joko Widodo rolled out the idea (Taufik, 2020). This is triggered by rampant juvenile delinquency, crime among students, the erosion of religious values and the noble values of Sundanese culture in society, especially among students.

The Purwakarta district government builds character through the 7 Poe Atikan Istimewa Purwakarta Istimewa program (Prawiyogi, 2019: 7). This is stated in the Purwakarta Regent Regulation Number 69 of 2015 concerning Character Education. In it there are XIV Chapters and 35 chapters. One of the things that will be used as study material is in article 5 paragraph 2 which contains the Seven Days of Special Purwakarta Education. This program aims to form a humanist young generation according to the values: cageur, bageur, bener, pinter jeung singer (Aziz, 2018: 16). In implementing this program, schools 
apply thematic elements and make them a philosophy in every learning activity in schools. Thus the educational process in schools has a different theme every day.

Tabel 2. "Tujuh Poe Atikan Purwakarta Istimewa" Program

\begin{tabular}{|c|c|c|c|}
\hline No & Days & Topic & Description \\
\hline 1. & Monday & Ajeg Nusantara & $\begin{array}{l}\text { Contains the meaning of growing a sense of nationality or } \\
\text { love for the country }\end{array}$ \\
\hline 2. & Tuesday & Mapag Buana & Contains the meaning of expanding horizons to the world \\
\hline 3. & Wednesday & Maneuh di Sunda & $\begin{array}{l}\text { Contains the meaning of returning to the Sundanese } \\
\text { identity }\end{array}$ \\
\hline 4. & Thursday & $\begin{array}{l}\text { Nyanding } \\
\text { wawangi }\end{array}$ & $\begin{array}{l}\text { Contains the meaning of providing space for freedom of } \\
\text { expression }\end{array}$ \\
\hline 5. & Friday & Nyucikeun Diri & Contains the meaning of getting closer to the Almighty \\
\hline 6. & Saturday & \multirow[t]{2}{*}{ Betah di Imah } & \multirow{2}{*}{$\begin{array}{l}\text { Contains the meaning of loving family as a place for family } \\
\text { shelter }\end{array}$} \\
\hline 7. & Sunday & & \\
\hline
\end{tabular}

\section{Local wisdom and islamic education values in strengthening character education in Purwakarta district}

Talking about the values of local wisdom, of course it will be different from one region to another so that the policy of strengthening character education in basic education units in each region will also be different. Sundanese local wisdom is a systematic guide based on the Sundanese philosophy of silih asah, slih asuh and silih wawangi (Fajrussalam \& Hasanah, 2018). This philosophy is then developed in schools in every educational and teaching activity at the basic education level in the Purwakarta district. This Sundanese philosophy is in line with the theoretical principles described by Benjamin S Bloom (in his book Taxonomy of Education of objectives Cognitive Domain, 1959), namely the attainment of the cognitive, affective, conative / psychomotor realms.

Tabel 3. The Value of Sundanese Local Wisdom in Strengthening Character Education

\begin{tabular}{|l|l|l|}
\hline & Sundanese Local Wisdom Values \\
\hline No & Value & Explanation \\
\hline 2. & Silih Asah $A s u h$ & $\begin{array}{l}\text { Value-oriented on improving the quality of thinking, sharpening the ability to } \\
\text { sharpen the mind by hammering knowledge and experience giving each } \\
\text { other experience and knowledge. In this context, we must teach each other, } \\
\text { must complement each other with knowledge, so that we all become humans } \\
\text { who have extensive knowledge. }\end{array}$ \\
\hline 3. & $\begin{array}{l}\text { Silih } \\
\text { Walue-oriented means a behavior or attitude that has empathy, compassion, } \\
\text { with each other must love each other. We have to help those who need our } \\
\text { help. }\end{array}$ \\
\hline & $\begin{array}{l}\text { Oriented to the meaning of providing positive values, having the ideals of a } \\
\text { well-ordered national society, where everyone knows their respective places } \\
\text { or positions and takes care of each other so that they become a harmonious } \\
\text { whole. }\end{array}$ \\
\hline
\end{tabular}

Generally speaking, Sundanese local wisdom values are an acculturation of Islamic teaching values and cultural norms of ancestral heritage. These values have the function of organizing the social life of the community. In Sundanese cultural values, there are at least four values, namely the value of harmony in life, respect for time, environmental values and respect for ancestors. Sundanese culture is influenced by Islamic teachings because almost all Sundanese people are Muslim (Kahmad, 2011: 136). Islamic teachings seem inseparable from the life and culture of the Sundanese people. So, there is the phrase "aneh lamun aya urang sunda lain Islam" means it is unusual if there are Sundanese people who are not Muslims. This can be seen from customary law or traditional ceremonies that are acculturated by Islamic teachings. Islamic values found in the Sundanese people which are raised in strengthening the character of elementary schools in Purwakarta district include the values contained in the Al-Qur'an Surat Luqman verses 12-19 (Budiyanti, Aziz, \& Palah, 2020: 6). The values contained are as follows (Fitri \& Idris, 2019: 35): Grateful to Allah (Q.S. Luqman: 12)

1. Associating others than Allah is the worst of all wrongs (Q.S.Luqman: 13) 
2. Nothing is hidden from Allah (Q.S.Luqman: 16)

3. Patience is a tough and important thing (Q.S.Luqman: 17)

4. Do not be arrogant and boastful (Q.S.Luqman: 18)

5. Be moderate in speaking and walking (Q.S.Luqman: 19).

\section{DISCUSSION}

\section{The Concept of Strengthening Humanistic-Based Character Education in Relation to Educational Policies in Purwakarta Regency}

Gusdur as the National Teacher, in 2006 said that the Indonesian nation had failed in the educational process in 5 ways, namely: (1) failing to teach history so that society no longer appreciates the merits of heroes; (2) failing to teach language so that sarcasm (language violence) appears everywhere. Javanese people can no longer read and write Javanese, Sundanese people can no longer speak Sundanese politely and can no longer write the original characters of their ancestors and so on; (3) failing to teach philosophy so that many people are no longer wise in making decisions; (4) failing to teach mathematics so that people's minds are inclined towards the mystical and superstitious; (5) failing to teach morals so that there are a lot of crimes, anarchism and terrorism in Indonesia (Fitri, 2020: 27).

What Gusdur said was a reality in the world of education that needed to be addressed. If education is seen as failing in building the character of the nation, then something is wrong and needs to be corrected in the current education system. The education system that is intended and appropriate for the Indonesian nation is education that can prepare students' subjects to be able to direct themselves individually and in groups in order to obtain provisions for achieving happiness in the hereafter (Urip, Kurniawati, \& Umam, 2019: 554). This nation's generation requires holistic self-development, including aspects of intellectual, emotional, and spiritual intelligence. Without this last aspect, it is difficult for someone to grasp the meaning of life. This is then an approach that is considered comprehensive and humanistic to be applied in character education in basic education in Purwakarta

So far, our educational practice is too western-oriented, forgetting the moral values and the superior characteristics of the wisdom values that exist in this Nusantara archipelago, especially in their respective regions. It is not wrong if we use knowledge and methods from the outside that seem westernized, it's just not to be swallowed up. We need to adapt the knowledge and methods according to the characteristics of this nation's education. So we should only use western knowledge and methods as tools, while the materials or educational content come from our own nation (Fitri, 2020: 56).

The humanistic approach is an approach in education that originates and develops from the west. We can adopt and adapt humanistic thinking about education that humanizes us according to the conditions of the characteristics of Indonesian education. Humans as divine beings and have a culture are in line with humanistic thinking about efforts to humanize humans (Muali, 2017: 413). Indonesia as a nation that puts forward the values of one God and humanity that is just and civilized, of course, requires a humanistic approach in achieving the goal of strengthening character education, especially at the basic education level in Purwakarta district.

One of the ways that the Purwakarta Regency Government has done is by the emergence of the Purwakarta Regent Regulation Number 69 of 2015 concerning Character Education. In Chapter III, article 5, paragraphs 1 and 2, it is explained about the 7 (seven) Poe Atikan Istimewa Purwakarta Education or 7 (seven) Special Purwakarta Education Teaching Days and the basic values of character education. Dedi Mulyadi as the former Regent of Purwakarta and the initiator of the Purwakarta character education program considered that character education is a way of shaping human characteristics and exploring the potential of students (Prawiyogi, 2019: 7). Children don't just learn in class, they study in rice fields, plant rice, graze buffalo, and grow various kinds of vegetables. From here, we also need to concoct character education that builds the character of Indonesian people based on culture and the values of belief in God Almighty. Through humanist character education is a strategy to achieve the goal of character education to form optimal students not only in the cognitive realm, but psychomotor and affective (Njoko, 2018: 9).

The exploration of local wisdom values as a basis for character education is in line with UNESCO's recommendations in 2009. UNESCO states that extracting local wisdom as the basis for character education and education in general will encourage mutual respect between ethnicities, tribes, nations and religions, so that diversity is maintained. Ki Hajar Dewantara, long ago told us how an educational curriculum that is not based on our cultural foundation, will lose its spirit and be unable to fill the inner space of the students. A curriculum without its own culture is like a boat without direction (Sari, 2018). Bung Karno, the Father of the Proclaimer, admitted that he did not make Pancasila, but he only mixed and summarized the various ancestral inheritances into a single, hierarchical and systemic philosophy of national life with the so-called Pancasila (Zubaedi, 2017: 178). 
The Purwakarta Character Program seeks to explore the potential of students to be able to compete in the global stage while maintaining national character through a religious approach and preservation of local wisdom that exists in Sundanese society. Sundanese culture is also a wealth for the Indonesian people and is one of the oldest cultures in the archipelago that needs to be preserved, cared for and preserved. Sundanese culture is heavily influenced by Islamic teachings because almost all Sundanese people are Muslims. Islamic teachings as inseparable from the life and culture of the Sundanese people. This can be seen from customary law or traditional ceremonies that are accredited by Islamic teachings. So there is the phrase "aneh lamun aya urang sunda lain Islam" which means an oddity if there are Sundanese people who are not Muslims (Isnendes, 2014: 194). This philosophical foundation has led to the character education curriculum policy at the elementary school level in Purwakarta. With this policy, the sustainability of education in Purwakarta district based on the "Tujuh Poe Atikan Purwakarta Istimewa" program must be integrated into various activities in schools with a breath of local wisdom and Islamic education values.

The process of extracting and re-internalizing local wisdom (religion and culture) internally in education and the learning process is a movement back to the basis of regional cultural values itself as a filter from the negative influence of other cultures. Referring to the National Policy for National Character Education, the Ministry of National Education has compiled a master design for character education. Its contents include, among other things, the basic framework, approaches and strategies for implementing character education. The character configuration is determined based on four psychosocial processes, namely thinking, heart, exercise and feeling (Kahmad, 2011: 63). If studied in depth, the character education policy in Indonesia leads to a humanistic approach in the character-building process by prioritizing the process and exploring various potentials that include the four psychosocials as described above.

If we examine the history of education in Indonesia, of course it cannot be separated from the thought of an educational figure, namely Ki Hajar Dewantara. In shaping student character, he implements a humanistic approach, in the implementation of education using the Among system as a manifestation of his conception of placing children at the center of the educational process. In the Among System, every teacher (pamong) as a leader in the education process is required to have the following attitude: Ing Ngarsa Sung Tuladha, Ing Madya Mangun Karsa, Tutwuri Handayani. These three slogans are used as the basic concept of character education; Ing Ngarsa Sung Tuladha, implies, a tutor or educator must be able to provide role models for their students. The educator as a leader must have a good attitude and behavior in all his steps and actions so that it can be used as a central figure for students. Ing Madya Mangun Karsa, Ingmadya implies that a leader in the midst of his busy life must be able to raise or arouse the morale of his subordinates. Therefore, a civil servant or educator as a leader should be able to develop the interest, desire and willingness of students to be creative and work, in order to devote themselves to noble and ideal ideals. Tutwuri Handayani, Tutwuri means an educator is a leader who must provide moral encouragement and morale from behind (Budiono, 2017: 46). From this description, we can develop a meaning that strengthening humanistic-based character education through local wisdom and Islamic education values is a planned and systematic effort carried out both formally and non-formally in a humane manner in order to prepare students who have a strong Muslim personality (insan kamil) based on the values of national identity and akhlakul karimah.

\section{Implementation of Strengthening Humanistic-Based Character Education through Local Wisdom and Islamic Education Values in Basic Education Units in Purwakarta district}

Character education that is applied at the primary school level in Purwakarta district is the cultivation of Islamic values and Sundanese culture. In its implementation, it is guided by the 7 Poe Atikan Purwakarta Istimewa program as stated in the Purwakarta Regent Regulation Number 69 of 2015 concerning Character Education. Character strengthening is carried out through learning, modeling, mentoring, habituation, motivating, cultivating, and enforcing rules. The goal is for students to be able to understand, experience, and integrate values and ethics into their personality. These efforts are carried out by 1 ) maintaining and protecting the potential of students; 2) develop all potential tendencies and talents of students in a better direction; 3) guiding the potential of students towards spiritual and physical maturity towards perfection; and 4) a gradual, continuous, whole and sustainable educational process (Njoko, 2018: 7).

On Monday, the theme is "Ajeg Nusantara", which means the language of "strong archipelago". Students are introduced to the archipelago, starting from its culture, potential, to its rich natural resources. As a generation that loves their nation, they should also be able to get to know their homeland (archipelago). This cultivates the nationalist character of the learners. Children carry out flag ceremonies, dress in scouting clothes, learn national and regional songs, and scout extracurricular activities. To get 
used to the practice of religious values, Muslim students (who are Muslim) also carry out the Sunnah fasting on Monday. Children are taught to give thanks to Allah by cultivating a spirit of nationalism through cultural preservation and implementing Sunnah practices as contained in the values contained in the Al-Qur'an Surat Luqman verse 12 and Surat An-Nisa verse 66.

On Tuesday "Mapag Buana", means "to pick up the world". Students are given knowledge about the international world, both culture and science. To increase the motivation that Indonesian children have a global and global perspective so that they are ready for future challenges and compete on the international stage. Children learn and are introduced to international language (English) in the form of vocabulary and conversation. Children are directed to familiarize themselves with the school literacy movement by reading 15 minutes before learning. Children read books or information related to foreign countries and the latest international world. Children are taught to know and appreciate the culture of other nations as contained in the values contained in the Qur'an, Surat Luqman verse 18 and Surat AlHujurat verse 13. This educates children to develop independence, mutual cooperation, and integrity.

On Wednesday "Maneuh di Sunda", literally means "proud to be Sundanese". Education whose content contains Sundanese characteristics. On Wednesdays all students are required to wear a pangsi, head iket, and kebaya as symbols of the Sundanese people. Maneuh in Sunda is part of an effort to introduce regional culture and local potential, especially the potential and culture of the Sundanese people. Children learn Sundanese grammar, get to know traditional Sundanese songs, and Sundanese customary habits to communicate using Sundanese, including bringing food supplies containing Sundanese specialties to school. This educates children to have a simple life as the habits of the Sundanese society which are known to be humble and full of courtesy. This is the same as the values contained in Al-Qur'an Surat Luqman verses 18-19 and Surat An-Nahl verse 123. Children are trained to develop a love of their homeland by loving and preserving the wisdom of their ancestral culture.

On Thursday "Nyanding Wawangi", literally means "fragrant and spreads fragrance". Efforts to make Purwakarta students have character, one thing that needs to be motivated is the spirit of loving Sundanese cultural aesthetics and inheriting the spirit of art. The goal is to be able to bring the fragrance of their homeland. On this day, special students study aesthetics, literature, decorating rooms, and so on. In addition, students are directed to the potential talents and interests of each. On this day, there are arts extracurricular activities such as angklung, degung, pianika, dance and drumb-band. To get used to the practice of religious values, Muslim students (who are Muslim) also carry out the Sunnah fast on Thursday. This Thursday the "Beas Kaheman" program was held, as a form of children's love to bring rice from home to be collected and then distributed to those in need in the surrounding environment. Also held are religious extracurricular activities such as Qashidah, prayer practices, recitation of the Qur'an, hifzhil Qur'an and da'wah. Children are creative by collaborating with other children, they learn with joy and love each other. Children naturally practice the values of nationalism, mutual cooperation, independence and integrity. This is the same as the values contained in the Qur'an, Surat Luqman verses 16-17 and Surat An-Nahl verses 5-6.

On Friday "Nyucikeun Diri", literally means "to purify oneself". Learning contains spiritual values and cleanliness. As religious people who love cleanliness and self-purity, Purwakarta students must maintain the purity of their hearts, souls and minds in order to stay awake and always close to God by way of worship. Children perform dhuha prayers together, read Al-Qur'an, prayer, Asmaul Husna, and wear Muslim clothes. On Fridays, children are educated to train themselves to do prayer through the GASIBU (One Thousand Day Movement) program. This is a form of purifying oneself before Allah as contained in the Word of Allah Q.S. At-taubah verse 103. Children are taught that Allah is the Creator of the Essence, there is no one who equals Him, and Allah knows everything that is visible or hidden. This develops a religious and independent character for children as the values contained in the Al-Qur'an Surat Luqman verses 12-13.

On Saturdays and Sundays "Betah di Imah", means "at home". Students on Saturdays and Sundays do vocational learning by helping parents with chores at home. Students are accustomed to feel at home, do activities together, cook, chat, chat, love spoiled parents. Students are required to help with their parents' work. This program seeks to bring students closer to their siblings, family and community in their home environment. Students can understand various family problems faced, give advice to one another, discuss, and exchange ideas among family members. The child is devoted to two parents (Birul Walidain) as a form of gratitude to Allah. Children develop independent and religious character with their families at home. This is the same as the values contained in the Qur'an, Surat Luqman verse 12 and Surat Al-'Isra verses 23-24.

The development of character education based on local wisdom carried out at the elementary school level in Purwakarta district consists of several components, namely: (1) objectives; (2) program; (3) process; (4) evaluation (Aziz, 2016). Character education is not included as a subject matter in formal 
subjects but is integrated into various subjects, local content, self-development and school culture. These values are integrated and developed into the curriculum, learning syllabus and learning program plans. The learning principle developed is to strive for students to recognize and accept the values of Islamic character and Sundanese cultural values as their own. The learning objectives are aimed at shaping children in a humane way according to the philosophy of life which becomes a Sundanese character as a path to the virtue of life. The Sundanese characters referred to are cageur (healthy), bageur (good), bener (correct), singer (introspective), and pinter (intelligent). Children are directed to be responsible for their choices through the stages of recognizing choices, determining convictions, and making values according to their beliefs. With this principle, students learn through a process of thinking, behaving and acting which aims at developing the ability to carry out social activities and encouraging students to see themselves as social creatures. Children learn by prioritizing four pillars of education, namely: (1) learning to know, (2) learning to do (3) learning to be, dan (4) learning to live together.

The learning process is carried out actively and pleasantly through student-centered learning. The teacher guides and provides examples for students. The teacher teaches the children about 3 -character sentences, namely "Thank You, Sorry, and Help". The learning method applied in learning is in the form of scientific learning, problem-based learning, inquiry learning and contextual learning. It trains the child to think critically and possess the higher-order thinking skills required for problem solving. Through student centers, children are trained to develop 4 C's (collaborative, critical thinking, creative \& communicative). Learning assessment is oriented towards an objective assessment of the process based on five indicators of value in strengthening character education, namely religious, national, integrity, independent and mutual cooperation.

Tabel 4. Student Scores in Strengthening Character Education

\begin{tabular}{|l|l|l|l|}
\hline No & $\begin{array}{l}\text { Value } \\
\text { Dimension }\end{array}$ & Sub Value & Score \\
\hline 1 & Religious & a. Love peace, & 4.19 \\
\hline & & b. Tolerance & 3.89 \\
\hline & & c. Respect differences in religion and belief & 4.33 \\
\hline & & d. Anti bullying and violence & 4.02 \\
\hline 2 & Nasionalist & a. Willing to sacrifice & 3.98 \\
\hline & & b. Excellence and achievers, & 3.77 \\
\hline & & c. Love the country, & 4.03 \\
\hline & & d. Protect the environment, & 4.12 \\
\hline & & e. Obey the law & 3.68 \\
\hline & & f. Discipline, & 4.05 \\
\hline & & g. Respect cultural, ethnic and religious & 3.98 \\
\hline 3 & Independent & a. Workethic (hard work), & 4.22 \\
\hline & & b. Professional & 4.04 \\
\hline & & c. Creative. & 4.34 \\
\hline 4 & Integrity & a. Honesty & 4.55 \\
\hline & & b. Anti-corruption, & 3.86 \\
\hline & & c. Fairness & 4,03 \\
\hline & & d. Responsibility. & 4.31 \\
\hline 5 & Cooperation & a. Respect & 4.05 \\
\hline & & b. Cooperation, & 4.18 \\
\hline & & c. Commitment to joint decisions, & 4.33 \\
\hline & d. Deliberation to reach a consensus, & 4.30 \\
\hline & & e. Please help & 3.89 \\
\hline & f. Solidarity. & 3.99 \\
\hline
\end{tabular}

Character strengthening in elementary schools in Purwakarta district is developed through school-based management. Student activities in life skills are adjusted to the potential of their respective areas such as gardening, farming, raising livestock, planting trees, raising animals at home, fishing, and doing ecoliteracy through ecobricks. Meanwhile, strengthening religious values in students is developed through learning the yellow book, reading and writing the Qur'an, and other worship practices. Currently, digital-based schools, child-friendly schools and environmentally friendly schools are being developed at the elementary school level in Purwakarta. 
Visionary and transformative leadership of school institutions is able to arouse or inspire organizational morale to achieve educational goals through school-based management. Educational policies also strengthen the principles of values that are the basis for the implementation of character education in schools. Supported also by the provision of supporting facilities or infrastructure, this is realized by the development and provision of school facilities that are evenly distributed as needed, both in urban areas to remote rural areas. Facility support is very important in supporting school processes and conditioning so that character development can run effectively and efficiently.

Finland University in 2018 held a Sharing and Hearing event in the Purwakarta Regency Education Office, finding a similar pattern between the implementation of character education in Purwakarta and Finland. Education does not burden children, students experience happiness when receiving lessons, focusing on children's skills and abilities. From the curriculum aspect, the lessons included in the curriculum are adjusted according to the local school. Purwakarta is considered to be doing the same thing as Finland by implementing a curriculum in accordance with regional characteristics. So, there are differences between one school and another, according to the character of the region (Maldiansyah, 2018).

Strengthening humanistic-based character education through local wisdom and the values of Islamic education at the basic education level in Purwakarta district, is basically an effort to preserve and instill Islamic and cultural values from an early age in students. This is an effort in order to prepare students to have a strong Muslim personality (Insan Kamil) based on the values of national identity and akhlakul karimah. Students have broad insight, are able to compete and collaborate on the global stage while still maintaining the existence of Indonesian character values.

\section{CONCLUSION}

The implementation of strengthening humanistic-based character education in the district of Purwakarta is carried out based on the 7 Poe Atikan Purwakarta Istimewa program as stated in the Purwakarta Regent Regulation Number 69 of 2015 concerning Character Education. Character strengthening in elementary schools in Purwakarta district is developed through school-based management. Supported by visionary and transformative leadership of school institutions, humanist education policies and provision of adequate facilities so as to arouse or inspire organizational morale to achieve educational goals through school-based management.

The values of character education are integrated and developed into the curriculum, learning syllabus, and learning program plans. The learning process is carried out actively and pleasantly through student-centered learning. Education is conditioned not to burden children, students experience happiness when receiving lessons, the educational process focuses on children's skills and abilities. Learning aims to shape children in a humane manner as the philosophy of life of Sundanese cultural characters, namely cageur (healthy), bageur (good), bener (correct), singer (introspective), and pinter (intelligent). Children learn by prioritizing four pillars of education, namely: (1) learning to Know, (2) learning to do (3) learning to be, and (4) learning to live together. Learning assessment is oriented towards an objective assessment of the process based on five indicators of value in strengthening character education, namely religious, national, integrity, independent and mutual cooperation.

\section{REFERENCES}

Anshari, M. Z., \& Widyantoro, A. (2020). Inculcating Islamic values contented in Qs. Luqman through english speaking materials. Journal of Education and Learning (EduLearn), 14(1), 62-68. https://doi.org/10.11591/edulearn.v14i1.14285

Aziz, H. (2018). Analisis Kebijakan Pemerintah Purwakarta tentang Pendidikan Karakter Berbasis Kearifan Lokal di Kabupaten Purwakarta. Golden Age: Jurnal Pendidikan Anak Usia Dini, 2 (1), 11-18. https://doi.org/10.29313/ga.v2i1.4167

Baharrudin \& Makin. (2011). Pendidikan Humanistik Konsep, Teori dan Aplikasi Praktis dalam Dunia Pendidikan. Jogjakarta: Ar-Ruzz Media.

Budiono. (2017). Pendidikan Humanistik Ki Hajar Dewantara dalam Perspektif Pendidikan Islam. Intelektual, 7, 42-53.

Budiyanti, N., Aziz, A., \& Palah. (2020). the Formulation of the Goal of Insan Kamil As a Basis for the. IJECA (International Journal of Education and Curriculum Application), 3(2), 1-10. https://doi.org/10.31764/ijeca.v3i2.2252

Cece. (2019). Penguatan Pendidikan Karakter Melalui Kearifan Lokal Berbasis Al-Qur'an (Implementasi di SMAN Kabupaten Purwakarta). Yogyakarta: Deepublish. 
Durachman. (2014, 340-346). Peranan Orangtua, Guru, Dan Teman Sebaya Dalam Proses Pembentukan Karakter Siswa Sekolah Dasar [The Role of Parents, Teachers, and Peers in the Process of Character Building of Elementary School Students]. Papper presented at the National Conference on Primary Education of the Graduate School of the Indonesian University of Education, Indonesia.

Fajrussalam, H., \& Hasanah, A. (2018). Core Ethical Values of Character Education Based on Sundanese Culture Value. IJECA (International Journal of Education and Curriculum Application), 1(3), 15-19. https://doi.org/10.31764/ijeca.v1i3.2126

Fitri, A. (2020). Pendidikan Karakter Berbasis Nilai \& Etika di Sekolah. Jogjakarta: Ar-Rurzz.

Fitri, N., \& Idris, M. (2019). Nilai Pendidikan Islam dalam Qur'an Surah Luqman Ayat 1-19: Tinjauan Kognitif, Afektif, dan Psikomotorik. Al-Musannif, 1(1), 32-46. https://doi.org/https://doi.org/10.5281/zenodo.2667704

Hartono, Y., Haryanto, S., \& Asrowi. (2018). Character Education in the Perspective of Humanistic Theory: A Case Study in Indonesia. EDUCARE: International Journal for Educational Studies, 10 (2), 95-108.

Hude, D., Febrianti, N.A., \& C. (2019). Penguatan Pendidikan Karakter Melalui Kearifan Lokal Berbasis AlQur'an (Implementasi di SMAN Kabupaten Purwakarta). Alim Journal of Islamic Educatioan I (2), 389-400.

Isnendes, R. (2014). Estetika Sunda Sebagai Bentuk Kearifan Lokal Masyarakat Sunda Tradisional Dalam $\begin{array}{lllll}\text { Sawangan } & \text { Pendidikan } & \text { Karakter. } & \text { Edusentris, } & 194 .\end{array}$ https://doi.org/10.17509/edusentris.v1i2.145

Kahmad, D. (2011). Sosiologi agama, Potret Agama dalam Dinamika Konflik, Pluralisme, dan Modernitas. Bandung: Pustaka Setia.

Kusdarini, E., Sunarso, S., \& Arpannudin, I. (2020). The implementation of pancasila education through field work learning model. Cakrawala Pendidikan, 39(2), 359-369. https://doi.org/10.21831/cp.v39i2.31412

Latiep, A. . (2014, 440-448). Harapan Pendidikan Nasional Pada Jenjang Pendidikan Dasar Dalam Pembangunan Karakter Budaya Dan Daya Saing Bangsa. Papper presented at the National Conference on Primary Education of the Graduate School of the Indonesian University of Education, Indonesia.

Maldiansyah. 2018. Finlandia University Hearing dengan Disdik Purwakarta. https://www.pasundanekspres.co/jabar/purwakarta/kagumi-konsep-pendidikan-karaktergagasan-dedi-mulyadi/ diakses 10 Oktober 2020.

Moleong, L. J. (2018). Metodologi Penelitian Kualitatif. Bandung: PT Remaja Rosdakarya.

Muali, C. (2017, 412-418). Humanism Education: Affective Consideration in Character Education Conception. (September), Proceedings of the 1st International Conference on Education and Islamic Culture "Rethinking Islamic Education Toward Cultural Transformation" Faculty of Tarbiyah, Islamic Institute of Nurul Jadid Probolinggo, East Java, Indonesia, $14^{\text {th }}$ September 2017.

Muhammad, A., Suhaimi, Jabaliah, Sulaiman, Zulkifli, \& Zulfahmi, I. (2020). Character Education, Student Mental Revolution, and Industry 4.0: The Case of State Islamic Senior High Schools in Indonesia. International Conference on Progressive Education (Icope 2019), 132-135. https://doi.org/10.2991/assehr.k.200323.105

Njoko, V. (2018). Strategi Komunikasi Politik Bupati Purwakarta Dedi Mulyadi Dalam Mensosialisasikan Program Pendidikan Berkarakter Purwakarta. E-Komunikasi 6(1), 1-11.

Paryana, Y. (2014, 319-325). Pendidikan Karakter Di Sekolah Dasar [Character Education in Primary Schools]. In Edison \& K. Anggraeni (Eds.), Papper presented at the National Conference on Primary Education of the Graduate School of the Indonesian University of Education, Indonesia. (pp. 319-325). Bandung: SPs Universitas Pendidikan Indonesia.

Permatasari, I., \& Hakam, K. A. (2018). The Development of Character Education Based on Sundanese Local Wisdom. IOP Conference Series: Earth and Environmental Science, 145(1). https://doi.org/10.1088/1755-1315/145/1/012124

Prawiyogi, A. (2019). Kajian Tujuh Poe Atikan Pendidikan Purwakarta Istimewa Dalam Peraturan Bupati Nomor 69 Tahun 2015. 2(22), 1-13.

Rahim, A., Raisul, S., \& Abdoludin, I. (2016). Character Issues : Reality Character Problems and Solutions through Education in Indonesia. Journal of Education and Practice 7 (17), 158-165.

Sugiyo, R \& Purwastuti, L.N. (2017). Local Wisdom-Based Character Education Model in Elementary School in Bantul Yogyakarta Indonesia. Sino-US English Teaching, 14(5), 299-308. https://doi.org/10.17265/1539-8072/2017.05.003

Sari, M. K. (2018, 201-205). Patterns of Child Friendly Education Through the Among System and Traditional Game Teachings of Ki Hadjar Dewantara. Proceeding of International Conference On Child-Friendly Education. 
Subaidi. (2020). Strengthening Character Education in Indonesia: Implementing Values From Moderate Islam and The Pancasila. Journal of Social Studies Education Research, 11(2), 120-132.

Suherman, A., Supriyadi, T., \& Cukarso, S. H. I. (2019). Strengthening National Character Education Through Physical Education: An Action Research In Indonesia. International Journal Of Learning, Teaching And Educational Research, 18(11), 125-153. https://doi.org/10.26803/ijlter.18.11.8

Taufan \& Sapriya. (2018). Pelembagaan Karakter Toleransi Siswa Melalui Program. Citizenship Jurnal Pancasila dan Kewarganegaraan 6 (1), 17-28. http://e-journal.unipms.ac.id/index.php/citizenship

Taufik, M. (2020). Strategic Role of Islamic Religious Education in Strengthening Character Education in the Era of Industrial Revolution 4.0. Jurnal Ilmiah Islam Futura, 20(1), 86. https://doi.org/10.22373/jiif.v20i1.5797

Urip, S. R., Kurniawati, N., \& Umam, K. (2019, 551-556). The Role of Pragmatics in Developing Humanistic Character of French Language Students. papper Presented at 1st International Conference on Education, Social Sciences and Humanities (ICESSHum 2019). https://doi.org/10.2991/icesshum19.2019 .88

Usman, A. H. (2017). Humanism In Islamic Education : Humanism : Historical Perspectives The term " humanism " has a complex history and meaning . " Humanism " as The humanist movement evolved and became the forerunner of the In the early blooming of humanism in Europe, human. Ijaps, 13(1), 95-113.

Zubaedi. (2017). Strategi Taktis Pendidikan Karakter (Untuk PAUD dan Sekolah). Depok: Rajawali Pers. 